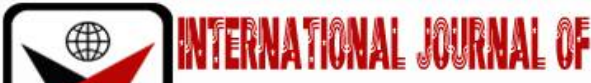

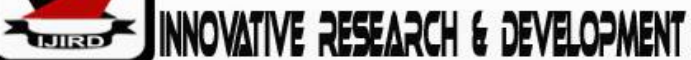

ISSN 2278-0211 (Online)

\section{Gender Violence, Human Right and Peace Building in South Sudan: A Case of Central Equatoria State Human Right Commission, South Sudan}

\author{
Dr. Gabriel Alier Riak Achot \\ Associate Professor, Department of Political Science \\ Upper Nile University, South Sudan
}

\begin{abstract}
:
The study focused on Gender violence, Human Right and Peace building in South Sudan. It assessed the relationship between Gender violence, Human right and peace building in South Sudan. The objectives of the study were to; examine the relationship between human right and peace building, relationship between gender violence and Peace building and study the factor structure on Gender violence, human right and Peace building. The research design was across- sectional and descriptive and using both qualitative and quantitative approaches in collecting data from the study population totaling 225respondents.

Sampling technique was used to select the sample of 183 respondents from the employees of the three NGOs and community members of Juba County. Data was analyzed using descriptive analysis option of SPSS version (18.0), and was then presented using Spearman's correlation, multiple regression and factor structure loadings of the relationship and prediction for Governance, Education, International communities and Peace building.

The results in indicated that a significantly strong positive relationship between Gender Violence and Peace Building (0.798, P-value \& lt;0.01). This implies that Gender Violence has a negative relationship with Peace Building. Thus, the question of whether Gender violence has a negative relationship with peace building in the Jubek was answered as true. The implication of these findings is that without local government campaigns for gender violence, peace building will not be achieved in Jubek.
\end{abstract}

Keywords: Gender violence, human rights and peace building

\section{Introduction}

The chapter introduces the study, with background that highlight on the key variable and purpose of the study. Problem Statement, The objectives and research questions are given as a stream line to the nature of the study carried out by the researcher. The scope of the study, conceptual frame work and significance of the study are presented and discussed.

\subsection{Background of the Study}

According to the United Nations General Assembly (2013), gender based domestic violence involves men and women and usually results in physical, sexual, or psychological harm or suffering to the victims. It also includes threats of such acts, coercion or arbitrary deprivation of liberty. A study from World Health Organisation (2016) indicates that between $16 \%$ and $52 \%$ of women worldwide are physically assaulted by an intimate partner at least once in their lives. In addition, according to the Inter-American Development Bank's special report on domestic violence in 1999, gender based violence results in direct loss of money due to health care, police, court costs and productivity. Besides financial losses, gender based violence has also been identified as a contributory factor to maternal mortality rate by 55 percent (World Bank, 2013).

Further, the World Health Organisation in 1996 documented that, among women aged 15-44 years, gender violence often leads to death and disability. In addition, studies in India, Bangladesh, the USA, Papua, New Guinea and Peru indicate a high correlation between domestic violence and suicide rates (WHO, 1997). Statistics published in 1997 by the World Health Organization on studies conducted in 24 countries in America, Europe and Asia revealed that between $20 \%$ and $50 \%$ of the women interviewed reported that they suffered physical abuse from their male partners. Moreover, according to an international report on the status of women in 140 countries, the number of women reporting physical abuse by a male partner during the period $1986-1993$ was $21 \%$ to $60 \%$ (Neft \& Levine, 1997).

Besides, a study done in South Africa showed that one adult woman out of every six is assaulted regularly by her mate. In at least $46 \%$ of these cases, the men involved also abuse the women's children (Russell, 1991). In addition, a study in 
northern Nigeria found that $16 \%$ of female patients seeking treatment for STDs were children under the age of five and $10 \%$ of these were cases of incest (UNFPA, 1999).

In a representative sample taken from two districts of Uganda, women between 20-44 years reported that $41 \%$ had been beaten or physically harmed by a partner (Blanc et al, 1996). In Kenya, data collected from a Baseline survey among women in Nairobi indicated that $50 \%$ of women interviewed reported an experience of domestic violence thus indicating a reasonably high prevalence of the vice. Consequently, further research especially involving both men and women in other parts of the country has been recommended (Federation of women lawyers (FIDA, 2001). In Kitui district research on gender based domestic violence has not been done. However surveys on human rights violation have been conducted by FAIDA a non-governmental organisation where cases of gender violence take $80 \%$ of the total human rights violation acts in the district (FAIDA, 2002). This organisation further documented that $30 \%$ of these gender violence cases were reported from the central division of Kitui district.

The health consequences of Gender-based violence (GBDV) according to Heisse (2009) include short-term health effects that have non-fatal outcomes such as minor cuts, headaches, pains and bruises. In addition, the long-term health outcomes include organ damage, chronic disabilities, mental disorders, depression, pregnancy complications and even fatal consequences such as suicide and murder. For majority of women, the persistent insults, abuse, confinement, harassment and deprivation of financial and physical resources may prove more harmful than physical attacks and result in women living in a permanent state of fear and sub-standard, mental and physical health (UNFPA, 1999). In support of this, the WHO information tool on violence notes that women have reported that the mental torture and living in fear and terror was undoubtedly the worst and most profound and long-lasting aspect of gender-based violence (WHO, 1997). For many countries, the economic cost of gender based domestic violence is substantial. For example, in Canada, a 1995 study estimated that violence against women cost the country 1.5 billion Canadian dollars in reduced labour productivity, and increased medical and community support services (UNICEF, 2007). Often, those who experience physical abuse end up using more medical services due to later complications. Such increased demand for health care services and loss in terms of productivity has become a big milestone to economic development especially among the developing countries (UNPFA, 2009).

It has become increasingly clear that GBDV adversely affects men and women's well being although men's cases of abuse are rarely reported. However, the manifestations of GBDV often go undetected and a large number of women and men continue living through repeated abuse and assault without any recognition of their ordeal or adequate provision for care or support. Available information on the linkages between violence and psychological ailments comes primarily from research conducted in developed countries. As such, a lot of scientific evidence is required from developing countries.

Human rights are moral principles or norms that describe certain standards of human behaviour, and are regularly protected as legal rights in municipal and international law. They are commonly understood as inalienable fundamental rights' to which a person is inherently entitled simply because she or he is a human being,' and which are 'inherent in all human beings' regardless of their nation, location, language, religion, ethnic origin or any other status. They are applicable everywhere and at every time in the sense of being universal, and they are egalitarian in the sense of being the same for everyone. They are regarded as requiring empathy and the rule of law and imposing an obligation on persons to respect the human rights of others, and it is generally considered that they should not be taken away except as a result of process based on specific circumstances; for example, human rights may include freedom from unlawful imprisonment, torture and execution (Connell 2011).

The doctrine of human rights has been highly influential within international law, global and regional institutions. Actions by states and non-governmental organisations form a basis of public policy worldwide. The idea of human rights suggests that 'if the public discourse of peacetime global society can be said to have a common moral language, it is that of human rights.' The strong claims made by the doctrine of human rights continue to provoke considerable skepticism and debates about the content, nature and justifications of human rights to this day. The precise meaning of the term right is controversial and is the subject of continued philosophical debate; while there is consensus that human rights encompasses a wide variety of rights such as the right to a fair trial, protection against enslavement, prohibition of genocide, free speech, or a right to education, there is disagreement about which of these particular rights should be included within the general framework of human rights; some thinkers suggest that human rights should be a minimum requirement to avoid the worst-case abuses, while others see it as a higher standard. (Stiehm, 2010).

Many of the basic ideas that animated the human rights movement developed in the aftermath of the Second World War and the events of The Holocaust, culminating in the adoption of the Universal Declaration of Human Rights in Paris by the United Nations General Assembly in 1948. Ancient peoples did not have the same modern-day conception of universal human rights. The true forerunner of human rights discourse was the concept of natural rights which appeared as part of the medieval natural law tradition that became prominent during the European Enlightenment with such philosophers as John Locke, Francis Hutcheson and Jean-Jacques Burlamaqui, and which featured prominently in the political discourse of the American Revolution and the French Revolution From this foundation, the modern human rights arguments emerged over the latter half of the 20th century, possibly as a reaction to slavery, torture, genocide and war crimes, as a realization of inherent human vulnerability and as being a precondition for the possibility of a just society(Manchanda 2011).

Peacebuilding is an intervention that is designed to prevent the start or resumption of violent conflict by creating a sustainable peace. Peacebuilding activities address the root causes or potential causes of violence, create a societal expectation for peaceful conflict resolution and stabilize society politically and socioeconomically.(UNIFEM 2001).

The activities included in peacebuilding vary depending on the situation and the agent of peacebuilding. Successful peacebuilding activities create an environment supportive of self-sustaining, durable peace; reconcile 
opponents; prevent conflict from restarting; integrate civil society; create rule of law mechanisms; and address underlying structural and societal issues. Researchers and practitioners also increasingly find that peacebuilding is most effective and durable when it relies upon local conceptions of peace and the underlying dynamics which foster or enable conflict (Ginsburg 2002).

Even if peacebuilding has remained a largely amorphous concept without clear guidelines or goals, common to all definitions is the agreement that improving human security is the central task of peacebuilding. In this sense, peacebuilding includes a wide range of efforts by diverse actors in government and civil society at the community, national and international levels to address the root causes of violence and ensure civilians have freedom from fear (negative peace), freedom from want (positive peace) and freedom from humiliation before, during, and after violent conflict. (Goetz, Anne Marie, 2007.)

Although many of peacebuilding's aims overlap with those of peacemaking, peacekeeping and conflict resolution, it is a distinct idea. Peacemaking involves stopping an ongoing conflict, whereas peacebuilding happens before a conflict starts or once it ends. Peacekeeping prevents the resumption of fighting following a conflict; it does not address the underlying causes of violence or work to create societal change, as peacebuilding does. It also differs from peacebuilding in that it only occurs after conflict ends, not before it begins. Conflict resolution does not include some components of peacebuilding, such as state building and socioeconomic development (Shireen Hassim, 2002).

In 2007, the UN Secretary-General's Policy Committee defined peacebuilding as follows: 'Peacebuilding involves a range of measures targeted to reduce the risk of lapsing or relapsing into conflict by strengthening national capacities at all levels for conflict management, and to lay the foundations for sustainable peace and sustainable development. Peacebuilding strategies must be coherent and tailored to specific needs of the country concerned, based on national ownership, and should comprise a carefully prioritized, sequenced, and therefore relatively narrow set of activities aimed at achieving the above objectives.

\subsection{Problem Statements}

Unlike the wars of old where objectives were known, the parties determinate, the fighters participating as part of a fighting machine, rules guiding armed conduct well laid down and accepted by the parties to a conflict, the new conflicts are somewhat different. Now, the objectives are more diffuse; the parties somewhat indeterminate; the fighters each driven by personal or collective grievance or motivation; and it is an all and out war with no barriers or forbidden targets. The challenge to conventional strategies and tactics has also meant that non-conventional participants in war have been drawn in as the new modes of warfare appear to have no barriers/rules. The changing nature of war has thus succeeded in blurring the distinctions between civilian and military, combatant and non-combatant, victim and perpetrator, all of which categories had implications under humanitarian and human rights law. The September 9th 2001 (9/11) terrorist attacks in the United States of America were aimed at the United States, but the choice of a target known to house global representation of people and interests, as well as the use of airplanes, which have become the key means of transportation in a globalized world, were by no means accidental. In one fell swoop, the leadership of Al Qaeda, who planned and executed those attacks, 'globalized' the conflict in what amounted to a hostile confrontation with the whole world. Their action thus transcended attacks on one world power, by taking on the symbols of globalization. This thinking appears to be the basis of attacks on trains and train stations in UK and Belgium, hotels and entertainment venues in France, Mali, Burkina Faso U.S. and Cote d'Ivoire and now a Russian airplane and an international airport in Belgium. All of these show clearly an expansion of the notion of 'Them vsUs' that underlies every conflict, with the 'democratization' of communication technology not being the less culpable. Thus, persons with extremist views and terror groups have successfully recruited others who but for information technologies, would otherwise have been completely out of their reach and scope; and by a number of mechanisms, such as 'franchising', 'radicalised lone wolf operatives' and by copy-cat operations, have made the determination of who qualifies as an 'enemy combatant' a difficult task. This has been made worse by the easy availability of online information on bomb-making and other IEDs, rendering otherwise law abiding and unarmed people into lethally-armed warriors. From heavy weapons indiscriminately used, 'human bombs' deliberately detonated in crowded areas to cause maximum casualties; these groups have stopped at nothing to press their point. Initially presented and characterized as a clash between Islamic and secular western civilizations, it has become clear that such characterization could not be entirely accurate on account of the large number of their co-religionists who have been targeted, attacked and massacred as part of the groups' modus operandi. All of these developments have changed the dynamics of conflict for the international community, and truly globalized the contest for hearts and minds, leaving the world baffled as to what to do next. In the midst of all this confusion, there is the loud sloganeering of 'African solutions for African problems'. What and where are the ideas with which Africa intends to confront these manifestations of conflict on the continent? The need for research into causes and effects, as well as the modes of response and the efficacy of existing tools in the management of the conflicts of today is almost self-evident. (Commission on Human Security. 2013)

While the international community is wrestling with these challenges, some of the groups involved in acts of violent extremism and terrorism, such as ISIL, Boko Haram and Al Qaeda in the Maghreb (AQIM) claim to be fighting to create Caliphates and establish Islamic forms of government, with no regard for existing national boundaries. Indeed, they desire to displace them all - a posture in complete contradiction to the post-Westphalian State, and International Law as currently practised. Again, their goals are maximalist, and do not admit of moderation, dialogue or negotiation. Thus, just as the unanticipated eruption of intra-state wars in the immediate post-cold war period challenged the instruments the international community had designed for dealing with conflict between and among its member states, so these emerging forms of conflict are challenging the available tools. Mechanisms for exacting compliance and for sanctioning leaders by putting them on travel bans etc; have been used to achieve desired outcomes when such persons have contravened norms 
of the community. Not so with these new protagonists of intra-state wars - non-state actors, who sometimes are even unaware of a legal regime of humanitarian law and of human rights; who have no need to travel or deal with the outside world such as to make travel bans effective as sanctions; and who have no external economic interests that could be blocked in order to force compliance with the standards and demands of the international community. Any African solutions would definitely make a contribution towards improving the efficacy of measures that could be employed to bring these aggressors to heel.

As if that were not enough complications to worry about, Africa's response to peace and security challenges based upon notions that there should be African solutions for African problems have come under pressure. The African Peace and Security Architecture (APSA) has been fashioned on the nature and manifestation of the features of the threats of yesterday. (Caroline and Andy Norton. 2012)

Its Panel of the Wise and Friends of the Panel are ready to mediate and negotiate with parties in conflict, but these new protagonists are not interested in such negotiation because first, they are not ready to emerge from the shadows, and second, they are in an all-or-nothing contest. On the military front, one of APSA's central pillars, the African Standby Force (ASF), is a continental military arrangement organised around the five regional groupings in Africa: North, South, East, West and Central. This has caused its existing economic communities or other regional bodies or mechanisms (RECs/RMs) - - NARC, ECOWAS, ECCAS, EASF, SADC to undergo fundamental mission shifts in order to support military action under the so-called principle of subsidiarity. However, while the ASF is still being formed and only now getting operational, a terrorist group such as Boko Haram has emerged with operations across four countries - Nigeria, Niger, Chad and Cameroon - two of which are in the West African community of ECOWAS and the other two in the Central African community of ECCAS. This has presented an immediate challenge to the design of the ASF; thus undermining the efficacy of existing arrangements and blunting the edge of the newly-designed instruments. This reality has necessitated the development of a new mechanism - the Lake Chad Basin Commission - of which all four affected countries are members. However, the task of fashioning new structures out of strictly civilian ones for the management of the resources of Lake Chad, to now offer a military response has been caught up in issues of hegemonic politics and other considerations. All of these developments have created new security challenges for governments and their security apparatuses as well as challenges to the tools that had been fashioned out to deal with the continent's existing challenges.

Yet another trait manifested by, ISIL and Boko Haram on the one part and Al Qaeda and Al Qaeda in the Maghreb (AQIM) on the other, is the effort to join forces to perpetrate outrages. Thus, Boko Haram has sworn loyalty to, and been accepted, by ISIL, whilst AQIM is clearly a branch (or franchise) of Al Qaeda. This has not only increased its reach, and possible access to heavy weaponry, but has also placed West Africa at the centre of possible turf wars between the two groups, for they are known to be bitter rivals. A realistic appreciation of these challenges would suggest that new thinking is required since the 'enemy' is not a determinate entity restricted to the theatre of war, but everyone whose death would produce terror and headlines in the news media. The world has now been set on its head, as with baffled exclamations it struggles to combat the new threats with its outdated weapons/responses. What can we do? What must we do? Clearly, new and fresh thinking is required, and this is where academic thinkers and theorists could make a difference.

In 2014, the appointment of the High-level Independent Panel on Peace Operations (HIPPO), coincided with the appointment of two other Panels by the General Assembly to review the implementation of Security Council Resolution 1325 on Women Peace and Security, and to advise it on its Peacebuilding agenda. These three Reviews operated concurrently and so were able to profit from synergies of joined up consultations. Indeed, the Chair and one other member of the 1325 Panel were fully-fledged members of the HIPPO as well, and this made for easy and meaningful linkages. Beginning its work in November, 2014, and handing in its report titled 'Politics, People and Partnership' in June, 2015, the HIPPO engaged in extensive consultations with all the major stakeholders to rebuild the lost consensus on peacekeeping and reaffirm the role of the UN in managing threats to international peace and security

\subsection{Purpose of the Study}

The purpose of this study was to identify the Gender violence, Human right and Peace building in Jubek state case of south Sudan Human right Commission.

\subsection{Objectives of the Study}

The objectives of the study were:

- To identify the relationship between Gender violence and peace building in South Sudan.

- To examine relationship between Human Rights and Peace Building in South Sudan.

- To Analyses factor Structure of Gender Violence, Human Wright and Peace Building

\subsection{Research Questions}

- What is the relationship between Gender violence and peace building in South Sudan?

- What is the relationship between Human Wright and Peace Building in South Sudan?

- What are the factor Structure of Gender Violence, Human Wright and Peace Building?

\subsection{Scope of Study}

The purpose of the study is to examine the relationship between the Gender Violence, Human right and Peace building in south Sudan case of Human right Commission. 


\subsubsection{Geographical}

The study will be carried out in the Human right Commission Headquarters

\subsubsection{Subject Scope}

Due to limited resource in term of time and finances, this study confined its focuses to the effects of Gender Violence, Human right and Peace building in South Sudan

\subsubsection{Time Scope}

The study will be carried out for the period of five mouths from September to May 2020

\subsection{Significance of the Study}

- Planning \& monitoring governments set the overall direction for their municipalities through long-term planning. Examples include council plans, financial plans, municipal strategic statements and other strategic plans. Setting the vision, and then ensuring that it is achieved, is one of the most important roles of local government.

- Service delivery Local government is responsible for managing and delivering a range of quality services to their communities, such as public health and recreational facilities, local road maintenance, and public libraries.

- Lawmaking \& enforcement governments legislate and make decisions in areas over which they have legislative authority. Local laws are not allowed to replicate or be inconsistent with state and federal laws or the operative planning scheme.

The laws made by local governments are called local laws and cover issues such as the activities permitted on public land, animal management, and use of infrastructure. iv. Policy development the activities of local governments are guided by policies. Developing and implementing these policies are key functions.

\subsection{Conceptual Frame Work}

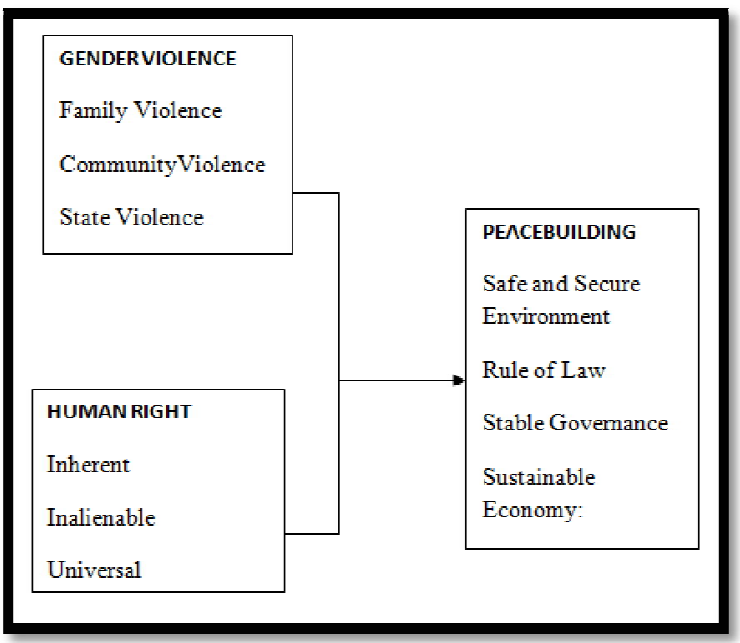

Figure 1

Sources: Self Developed By Researcher 2017

From the diagram above the structure of the conceptual frame work determine the nature on how the variables do interrelate. Therefore, the structure above determined the relationship between the variables on how they should accomplished the goal by either effects (positively or (negatively).

\section{Literature Review}

\subsection{Introduction}

Literature review is the process of identifying, evaluating, synthesizing and presentation of all relevant information from other sources like scholarly journals, publications, magazines and internet. Literature review reveals what strategies, procedures and measuring instruments have been found useful in investigating the problem in question. This chapter therefore represents the review of theoretical literature, critical literature and the gaps to be filled by assessing the relationship between the variables and their attributes

\subsection{Relationship between Gender Violence and Peace Building}

\subsubsection{Gender Violence}

According to the United Nations General Assembly (2013), gender based domestic violence involves men and women and usually results in physical, sexual, or psychological harm or suffering to the victims. It also includes threats of such acts, coercion or arbitrary deprivation of liberty. A study from World Health Organisation (2016) indicates that between $16 \%$ and $52 \%$ of women worldwide are physically assaulted by an intimate partner at least once in their lives. In 
addition, according to the Inter-American Development Bank's special report on domestic violence in 1999, gender based violence results in direct loss of money due to health care, police, court costs and productivity. Besides financial losses, gender based violence has also been identified as a contributory factor to maternal mortality rate by 55 percent (World Bank, 2013).

Further, the World Health Organisation in 1996 documented that, among women aged 15-44 years, gender violence often leads to death and disability. In addition, studies in India, Bangladesh, the USA, Papua, New Guinea and Peru indicate a high correlation between domestic violence and suicide rates (WHO, 1997). Statistics published in 1997 by the World Health Organization on studies conducted in 24 countries in America, Europe and Asia revealed that between $20 \%$ and $50 \%$ of the women interviewed reported that they suffered physical abuse from their male partners. Moreover, according to an international report on the status of women in 140 countries, the number of women reporting physical abuse by a male partner during the period 1986-1993 was $21 \%$ to $60 \%$ (Neft \& Levine, 1997).

Besides, a study done in South Africa showed that one adult woman out of every six is assaulted regularly by her mate. In at least $46 \%$ of these cases, the men involved also abuse the women's children (Russell, 1991). In addition, a study in northern Nigeria found that $16 \%$ of female patients seeking treatment for STDs were children under the age of five and $10 \%$ of these were cases of incest (UNFPA, 1999).

\subsubsection{Family Violence}

Domestic violence (also named domestic abuse, battering, or family violence) is a pattern of behavior which involves violence or other abuse by one person against another in a domestic setting, such as in marriage or cohabitation. It may be termed intimate partner violence when committed by a spouse or partner in an intimate relationship against the other spouse or partner, and can take place in heterosexual or same-sex relationships, or between former spouses or partners. Domestic violence may also involve violence against children or the elderly. It takes a number of forms, including physical, verbal, emotional, economic, religious, reproductive, and sexual abuse, which can range from subtle, coercive forms to marital rape and to violent physical abuse such as choking, beating, female genital mutilation and acid throwing that results in disfigurement or death. Domestic murders include stoning, bride burning, honor killings, and dowry deaths. (Madlala-Routledge2013).

Globally, the victims of domestic violence are overwhelmingly women, and women tend to experience more severe forms of violence. In some countries, domestic violence is often seen as justified, particularly in cases of actual or suspected infidelity on the part of the woman, and is legally permitted. Research has established that there exists a direct and significant correlation between a country's level of gender equality and rates of domestic violence. Domestic violence is among the most underreported crimes worldwide for both men and women. Due to social stigmas regarding male victimization, men face an increased likelihood of being overlooked by healthcare providers. (Graham and Jarvis 2011).

Domestic violence occurs when the abuser believes that abuse is acceptable, justified, or unlikely to be reported. It may produce intergenerational cycles of abuse in children and other family members, who may feel that such violence is acceptable or condoned. Very few people recognize themselves as abusers or victims because they may consider their experiences as family disputes that just got out of control. Awareness, perception, definition and documentation of domestic violence differs widely from country to country. Domestic violence often happens in the context of forced or child marriage.

\subsubsection{Community Violence}

This includes violence at the hands of a perpetrator unknown or unrelated to the woman and often comes in the form of rape, sexual harassment, forced prostitution or trafficking, and public humiliation. Community violence can be defined as exposure to intentional acts of interpersonal violence committed in public areas by individuals who are not intimately related to the victim. Common types of community violence that affect youth include individual and group conflicts (e.g., bullying, fights among gangs and other groups, shootings in public areas such as schools and communities, civil wars in foreign countries or 'war-like' conditions in U.S. cities, spontaneous or terrorist attacks, etc.). Although there are warnings for some types of traumas, community violence can happen with a sudden and terrifying shock. Consequently, youth and families that suffer from community violence often experience increased fears and feelings that the world is unsafe and harm could come at any time. In addition, although some types of trauma are accidental, community violence is an intentional attempt to hurt one or more people, including homicides, sexual assaults, robberies, and weapons attacks (bats, knives, guns, etc.) (U.N. 2002; UNIFEM 2002; Strickland and Duvvury 2003).

\subsubsection{State Violence}

This includes violations that are condoned and committed by individuals associated with the government. This is often seen in the form of violence at the hands of police, prison guards, refugee camp guards, border officials, and even peacekeeping troops. In conflict regions of the world, systematic rape and sexual violence is often used as a tool of war. (Moser and Norton 2011).

Totalitarian regimes throughout history, including those of Stalin, Hitler and Pol Pot, have used violence to terrorise populations into complying with the regime's demands. European colonial powers used violence in this way to establish and maintain their empires, and to try to thwart independence movements in their colonies. The allies during World War II bombed civilians in German cities to try and incite the public to turn against Hitler. The Latin American national security states during the Cold War, with significant support from the US, also deployed violence, including disappearances and torture, to try and curtail support for opposition movements. When non-state actors use violence to intimidate an audience beyond the direct victim of that violence, we refer to it as terrorism. Yet there has been 
considerable resistance within International Relations scholarship to the notion that states can be perpetrators of terrorism, even though the vast majority of state violence, particularly against domestic populations, is intended to have a terrorizing effect, and results in far higher casualties than non-state terrorism does. It is frequently assumed that because the existence of the state is based on its monopoly of coercive power, there is a fundamental difference. (The recent report of the Commission on Human Security (2003)

\subsection{To Examine the Relationship between Human Wright and Peace Building}

\subsubsection{Human Wright}

Human rights are moral principles or norms that describe certain standards of human behaviour, and are regularly protected as legal rights in municipal and international law. They are commonly understood as inalienable fundamental rights' to which a person is inherently entitled simply because she or he is a human being,' and which are 'inherent in all human beings' regardless of their nation, location, language, religion, ethnic origin or any other status. They are applicable everywhere and at every time in the sense of being universal, and they are egalitarian in the sense of being the same for everyone. They are regarded as requiring empathy and the rule of law and imposing an obligation on persons to respect the human rights of others, and it is generally considered that they should not be taken away except as a result of due process based on specific circumstances; for example, human rights may include freedom from unlawful imprisonment, torture and execution. (Amartya Sen 2011)

The doctrine of human rights has been highly influential within international law, global and regional institutions. Actions by states and non-governmental organisations form a basis of public policy worldwide. The idea of human rights suggests that 'if the public discourse of peacetime global society can be said to have a common moral language, it is that of human rights.' The strong claims made by the doctrine of human rights continue to provoke considerable skepticism and debates about the content, nature and justifications of human rights to this day. The precise meaning of the term right is controversial and is the subject of continued philosophical debate; while there is consensus that human rights encompasses a wide variety of rights such as the right to a fair trial, protection against enslavement, prohibition of genocide, free speech, or a right to education, there is disagreement about which of these particular rights should be included within the general framework of human rights; some thinkers suggest that human rights should be a minimum requirement to avoid the worst-case abuses, while others see it as a higher standard. (UNDP Report 2012)

\subsubsection{Inherent}

HumanRights are inherent because they are not granted by any person or authority. Human rights do not have to be bought, earned or inherited; they belong to people simply because they are human. Human rights are inherent to each individual (Bharath, Shumway, 2004).

\subsubsection{Inalienable}

Human rights cannot be taken away; no one has the right to deprive another person of them for any reason. People still have human rights even when the laws of their countries do not recognize them, or when they violate them for example, when slavery is practiced, slaves still have rights even though these rights are being violated. Human rights are inalienable.

\subsubsection{Universal}

Human Rights are universal in application and they apply irrespective of one's origin, status, or condition or place where one lives. Human rights are enforceable without national border. Human rights are the same for all human beings regardless of race, sex, religion, political or other opinion, national or social origin. We are all born free, and equal in dignity and rights - human rights are universal. (Bharath, Shumway, 2014)

\subsection{To Establish Factor Structure Between, Gender Violence, Human Wright and Peace Building}

Whether in time of war or peace, gender identities and the dynamic of gender relations carry a strong influence on a wide array of social, economic, and political outcomes.

Despite cultural variations, the consistent difference between women's and men's gender roles based in power influences women's access to and control over resources, their visibility and participation in social and political affairs, and their ability to realize their fundamental human rights. Such relationships have been explored in depth in a broad range of analytical literature on subjects as diverse as the operational analysis of political institutions, the gender analysis of budget processes and economic activity, and the causal factors and public responses associated with violence against women.

In the context of Amartya Sen's 2009 discourse on 'development as freedom,' social norms and institutional practices that discriminate against women represent an 'unfreedom' that constrains their capabilities by limiting such things as their political freedoms, economic facilities, and social opportunities. The capabilities of individuals -of women and men - and the measure of their human security depend upon institutional arrangements in economic, social, and political spheres that influence the process of development and require a corresponding plurality of institutions. In conflict-affected settings where most institutional arrangements may be altered or destroyed, it becomes especially important to consider how gender dynamics shape societal operations and policy outcomes both in the short term and in the longer term aftermath of conflict and reconstruction. Understanding such dynamics is essential for successful gender mainstreaming in peace processes. 


\subsubsection{Safe and Secure Environment}

A safe and secure environment is one in which the population has the freedom to pursue daily activities without fear of politically motivated, persistent, or large-scale violence. Such an environment is characterized by an end to largescale fighting; an adequate level of public order; the subordination of accountable security forces to legitimate state authority; the protection of key individuals, communities, sites, and infrastructure; and the freedom for people and goods to move about the country and across borders without fear of undue harm to life and limb. The most immediate concern is personal physical safety from violence. Even after the bulk of fighting is over, physical insecurity is often pervasive throughout society from politically motivated violence, rampant gunfire, retaliation by former enemies, gender based violence, landmines, and emerging armed criminal elements. State authority and security institutions, meanwhile, are likely to be politicized, part of the problem, and severely impaired or nonexistent, creating a security vacuum that insurgents, terrorists, extremists, or criminals will seek to fill. 3e security threats in transitional environments call for a dual capability to subdue large-scale threats to the peace process while also maintaining public order (Eijffinger, 2009)

\subsubsection{Rule of Law}

Ability of the people to have equal access to just laws and a trusted system of justice that holds all persons accountable, protects their human rights, and ensures their safety and security.

Rule of Law It is widely political consensus that the rule of law is a necessary foundation for efforts to achieve the goal of good governance. Justice is valued as central in governance. Therefore, it values justice as most important for establishing a just society in which people from all walks of life, from different faiths can live in peace and harmony with no discrimination. Equally important, good governance requires fair legal structure that must be applied objectively in order to give full protection to the human rights of the people, most especially those minorities. And, to implement this effectively, there must be unbiased implementation of laws that require independent judiciary and an impartial, as well as corrupt-free police force. Good governance is about the processes for making and implementing decisions. It's not about making 'correct' decisions, but about the best possible process for making those decisions. It is in this context, the study of good governance has become very important in the literature of political science, Administrative Sciences and development studies. Good governance is important for several benefits. First and foremost, quality of governance has to be judged by the performance of the relevant institution. Therefore, the goal of the institution has to be clearly defined as a matter of priority. Then, steering towards that goal requires defining decision rights and processes, as well as establishing a feedback loop to verify and control performance. Governance is how an institution is ruled; it is how the authority, responsibility, and controls are required in the institution. Governance is relevant to any institution, small or large; for profit or not; extending from a single family all the way to global institutions that have an impact on our lives. Hence, governance is relevant for humanity for quality of life now and for its sustainability in the future (Chava2013).

\subsubsection{Stable Governance}

Stable governance refers to an end state where the state provides essential services and serves as a responsible steward of state resources; government officials are held accountable through political and legal processes; and the population can participate in governance through civil society organizations, an independent media, and political parties. Stable governance is the mechanism through which the basic human needs of the population are largely met, respect for minority rights is assured, conflicts are managed peacefully through inclusive political processes, and competition for power occurs nonviolently. National and sub-national government institutions may work with a range of non-state partners to provide some of the government functions. Essential services- defined here as security, the rule of law, economic governance, and basic human needs services-are addressed fully in Sections and respectively. (walker 2013)

\subsubsection{Sustainable Economy}

Economic stability refers to an absence of excessive fluctuations in the macro-economy. An economy with fairly constant output growth and low and stable inflation would be considered economically stable (Shumway, 2011)

A financial system is stable when it dissipates financial imbalances that arise endogenously or as a result of significant adverse and unforeseeable events. When stable, the system absorbs shocks primarily via self-corrective mechanisms, preventing the adverse events from disrupting the real economy or spread over to other financial systems. Financial stability is paramount for economic growth, as most transactions in the real economy are made through the financial system.

Without financial stability, banks are more reluctant to finance profitable projects, asset prices may deviate significantly from their intrinsic values, and the payment settlement schedule diverges from the norm. Hence, financial stability is essential for maintaining confidence in the economy. Possible consequence of excessive instability includes: bank runs, hyperinflation, or stock market crashes. (The World Bank GFDR Report)

\section{Research Methodology}

\subsection{Introduction}

Research Methodology: is a systematic process used to collect information and data for the purpose of making a research. However, this chapter deal with the study/research design, study population, sample size, sample procedures, sample design, data source, research instrument, measurement of variables, data processing, data analysis and limitation to the study(Kothari 2012) 


\subsection{Research Design}

Magdalene M, (2010) a research design is the chronological order of things that result to answering research questions. This study used a descriptive research design. According to Cooper and Schindler (2006), a descriptive study is aims at finding out what, where and how of a phenomenon. This study therefore was able to generalize the findings of most of the banks. Hence the study is quantitative in that manner. On the other hand, the study uses a qualitative approach in an attempt to acquire a better understanding and hence lead to a better and more insightful interpretation of the results from the quantitative study. This method concerns the deep investigation of problem solving mechanism in which problems and solutions are relevant to the research problem. This strategy involves selecting of several targeted cases on which an intensive analysis is conducted. That helps in recognizing other possible ways for solving the research questions based on the present solution applied in the selected case study. The study brings out a subject, often by formulating a profile of group of problems (Cooper and Schindler, 2006). Descriptive survey design is flexible enough to provide opportunity for considering different aspects of a problem under study (Kothari, 2014).

\subsection{Study Population}

According to Sienna Chawla (2012) population is the number of all the organisms of the same group or species, which live in a particular geographical area, and have the capability of interbreeding.

The population under this project study is chosen from Juba County where a population of 75 bank's staff was chosen. This population will comprise the Civil Society 13, citizens 20 and women 25 . The choice of this population based on the belief that all kinds of people in this population know better and could provide relevant and required information for this study. However the table (Fig: 3.1.0) below shows the target Population

\subsection{Sample Size}

Basing on the table of Morgan \& Krejcie (2008) in Sekaran (2014), for a population of 75, a sample size of 63 would be representative enough, this population comprised of Civil Society 13, citizens 20 and women are 35.The researcher used stratified and purposive sampling to choose the respondents as per the table attached.

\subsection{Sampling Procedure}

Probability sampling method was applied to accommodate a variety of respondents. The method included stratified random sampling. Because the population was not homogeneous the researcher divided the respondents in the sampled groups into a number of stratum of which individuals sampled from each stratum was combined into one group which constituted the sample of the study.

\begin{tabular}{|c|c|c|c|}
\hline S/No & Juba County & Population & Sample Size \\
\hline 01 & Civil Society Activist & 13 & 12 \\
\hline 02 & Citizens & 20 & 19 \\
\hline 03 & Women & 35 & 32 \\
\hline 04 & Total & 75 & 63 \\
\hline
\end{tabular}

Table 1: Distribution of Targeted Staffs to Answer Questionnaires Source: Primary 2017

\subsection{Sample Design}

The study will be limited to stratify random sampling this is because the research would manage to cover the different categories of the bank departments as mentioned above.

\subsection{Data Sources}

Data is a fact and statistics collected together to for references or analysis about a particular study. However, there are two types of data these included primary and secondary sources of data.

\subsubsection{Primary Data}

Brown v (2009) this is a raw data collected on source which has not been subjected to processing or any other manipulation. This information was obtained mainly from the directors, and administrators (Top Management) of the bank.

\section{8. Research Instrument/Method}

The researchers employed the following primary and secondary methods of data collection because of it being reliable, accurate and time saving.

\section{$\underline{\text { 3.8.1 Questionnaires }}$}

Questionnaires are research instrument made up of a series of inquiries/questions and other prompts for the purpose of gathering or obtaining information from different respondents. This technique is used to collect the primary data by use of designed questions that goes through the required respondents. The questions will be open ended and close ended based on the predetermined and standardized questions (developed by researcher 2017). 


\subsubsection{Interview Guide}

Interviews will be carried out with the Senior Managers and tellers receiving and keeping inventory records in manual ledgers and printed papers. This was facilitated by the use of interview guides to acquire information on how different transactions are managed in the Bank. This method enabled the researcher to get direct feedback and interact with the respondents freely.

\subsubsection{Observation}

The investigator observed the tellers, and managers on how they interact with their citizens and the juba county. However, observation will be use to see how clients were being served by the bank staff and how information about each customer is stored/kept.

\subsection{Measurement of Variables}

Measurement of variables refers to the relationship among the values that are assigned to the attributes for a variable of any given topic of research. This can be achieved by the measurable values of Agreed, Strongly Agreed, Neutral, Disagreed and Strongly Disagreed, such that validity and reliability are ascertained.

\subsubsection{Validity}

The validity of an instrument means that, the instrument would measure exactly what it is expected to measure. This can be determined by using the expert judgment and through content validity Index formula in which the instrument will be considered valid when the (CVI) content validity index obtained is above 0.60 as recommended by (Lynn-2008).

\subsubsection{Reliability}

According to Reynaldo and Santos (2005), Reliability refers to the degree of consistency and accuracy that measuring instruments show. Therefore,

A test -re - test technique helps so much to attain the reliability of the questionnaire, most of the respondent who have earlier completed the questionnaire were asked to complete it again as part of standardization of the questionnaire to avoid mistake. The table shows the reliability test.

\begin{tabular}{|c|c|c|}
\hline Variable & Anchor & Cronbach Alpha \\
\hline Gender Violence & 5point & 0.897 \\
\hline Human Wright & 5point & 0.790 \\
\hline Peacebuilding & 5point & 0.823 \\
\hline
\end{tabular}

Table 2: Reliability Coefficients for Study Variables

\subsection{Data Processing}

Data processing is the method of editing, coding, classification and tabulation of collected data so that they are amenable to analysis. In the process of analysis, relationships or differences supporting or conflicting with original or new hypotheses should be subjected to statistical tests of significance to determine with what validity data can be said to indicate any conclusions'.

\subsection{Data Analysis}

Data analysis is the process of giving order, structure and meaning to the collected mass of information. The term data analysis refers to the computation of certain measures along with searching for patterns of relationship that exist among data-groups The aim of data analysis is to produce findings that relate to the problem motivating the researcher and to provide insights that contribute to decision-making process. The data collected from the field will be analyzed using the Statistical Package for Social Sciences (SPSS) 18.0 Software. The results obtained will be presented using statistics tools such as Tables.

\subsection{Ethical Consideration}

The researcher will be respecting the human dignity by not revealing the identity of the respondents in during the study. However, under an approval and a letter of introduction from the faculty of Business and Management studies will be got from the supervisor seeking permission to conduct the study after being directed by the supervisor to do so. This letter would be presented to the respondents in the study area for permission to conduct the study.

\subsection{Limitation to the Study}

During the of data collection, the researcher countered the following problems, Lack confident from the respondents, Insufficient communication, Irrelevant or duplicate data collected, Denial of information by some staff, Pertinent data omission, Erroneous or misinterpretation of questions, Poor documentation from other staff, Conflicting data and lack of equipment. But with all those, challenges, the researcher still made it through to obtain the necessary information/data for the completion of this research. 


\section{Analysis of Findings and Results}

\subsection{Introduction}

The chapter involves presentation, analysis and interpretation of the study results. Data presented, analyzed and interpreted according to the research objectives. It is presented in the form of tables and figures basing on the responses got from the study respondents that were selected during the process of data collection. The discussion of findings has been arranged in accordance with demographic characteristics of respondents' and objectives of the study as were formulated in chapter one of this report.

\subsection{Presentation and Analysis of Data collected Presentation:}

Out of 63 questionnaires, 62 were returned from the respondents. This gives a response rate of $99 \%$. This was a good result, as a result of follow up and the non-retrievable questionnaires were as a result of the negligence of Juba county staffs to fill their received questionnaire.

\subsection{Data Presentation Preliminary}

The table below shows the rate of response by different respondents.

\begin{tabular}{|c|c|c|}
\hline Questionnaires & Respondents & Valid Percentages (\%) \\
\hline Returned & 60 & 95 \\
\hline Not Returned & 3 & 05 \\
\hline Total & 63 & 100 \\
\hline
\end{tabular}

Table 3: Rate of Response by Respondents

Table 3A total number of 63 questionnaire where distributed and out of these 60 questionnaires were returned. Showing an average of $89.6 \%$ questionnaires. The number returned represents $95 \%$ of total questionnaires administered. However, this is a reasonable level upon which research can be based and valid conclusions can be drawn from the research

\subsubsection{SECTION A-Personal Bio-Data}

The Table 4 below shows the distribution of respondents by gender.

\begin{tabular}{|c|c|c|c|c|}
\hline \multicolumn{2}{|c|}{} & Frequency & Valid Percent & Cumulative Percent \\
\hline \multirow{3}{*}{ Valid } & Male & 38 & 72.1 & 72.1 \\
\cline { 2 - 5 } & Female & 15 & 27.9 & 100.0 \\
\cline { 2 - 5 } & Total & 63 & 100.0 & \multicolumn{3}{c|}{ Sable 4: Gender of Respondents } \\
\hline \multicolumn{4}{|c|}{ Source: Primary data. (2017) }
\end{tabular}

Table 4 shows that 38 out of the total of 63 respondents were males, representing approximately $72.1 \%$ of the entire sample size. While 15 were females, representing approximately $27.9 \%$ of the sample size.

The Table 5 below shows the distribution of respondents by age.

\begin{tabular}{|c|c|c|c|c|}
\hline \multicolumn{2}{|c|}{} & Frequency & $\begin{array}{c}\text { Valid } \\
\text { Percent }\end{array}$ & $\begin{array}{c}\text { Cumulative } \\
\text { Percent }\end{array}$ \\
\hline \multirow{6}{*}{ Valid } & $18-25$ & 15 & 23.3 & 23.3 \\
\cline { 2 - 5 } & $26-35$ & 36 & 48.8 & 72.1 \\
\cline { 2 - 5 } & $36-46$ & 9 & 13.9 & 86.0 \\
\cline { 2 - 5 } & $56-60$ & 6 & 4.7 & 90.7 \\
\cline { 2 - 5 } & above 60 & 7 & 9.3 & 100.0 \\
\cline { 2 - 5 } & Total & 64 & 100.0 & \\
\hline
\end{tabular}

Table 5 can be deduced that out of 63 of the total respondents, 10 were between the 18-25 years representing $23.3 \%, 21$ were between 26-35 years representing 48.8\%, 6 were between 36-46 years representing $13.9 \%, 2$ were between 56-60 years representing $4.7 \%$ and 4 were above 60 years representing $9.3 \%$ this implies that majority were between the age group of 26-35 which give county energy needed during the working progress. The Table 6below shows the distribution of respondents by marital status. 


\begin{tabular}{|c|c|c|c|c|}
\hline \multicolumn{2}{|c|}{} & Frequency & Valid Percent & Cumulative Percent \\
\hline Valid & Single & 9 & 11.6 & 11.6 \\
\cline { 2 - 5 } & Married & 35 & 48.8 & 60.4 \\
\cline { 2 - 5 } & Divorced & 13 & 18.6 & 79.0 \\
\cline { 2 - 5 } & Separated & 7 & 4.7 & 83.7 \\
\cline { 2 - 5 } & Widowed & 11 & 16.3 & 100.0 \\
\cline { 2 - 5 } & Total & 63 & 100.0 & \\
\hline
\end{tabular}

Table 6: Marital Status of the Respondents

Source: Primary Data. (2017)

Table 4.2.3it can be deduced that out of 75 of the total respondents, 5 were single, representing $11.6 \%, 21$ were married representing 48.8\%, 8 were divorced, representing 18.6\%, 2 were separated, representing $4.7 \%$ and 7 were widowed, representing $16.3 \%$

The Table 7 below shows the distribution of respondents by academic qualification.

\begin{tabular}{|c|c|c|c|c|}
\hline \multicolumn{2}{|c|}{} & Frequency & $\begin{array}{c}\text { Valid } \\
\text { Percent }\end{array}$ & Cumulative Percent \\
\hline \multirow{3}{*}{ Valid } & Senior school certificate & 15 & 25.6 & 25.6 \\
\cline { 2 - 5 } & Diploma & 9 & 11.6 & 37.2 \\
\cline { 2 - 5 } & Bachelor & 38 & 46.5 & 83.7 \\
\cline { 2 - 5 } & Masters & 12 & 16.3 & 100.0 \\
\cline { 2 - 5 } & Total & 63 & 100.0 & \\
\hline
\end{tabular}

Table 7: Academic Qualification of Respondents

Source: Primary Data. (2017)

Table 4.2.4it can be concluded that out of 75 of the total respondents, 11 were Senior School Certificates, representing 25.6\%, 5 were having diploma representing $11.6 \%$, 30 were Bachelor holders, representing $46.5 \%$ and 9 were Master holders, representing $16.3 \%$ this implies that the county has highly qualified staffs. Table The table 4.6 below shows the distribution of respondents by working experience.

\begin{tabular}{|c|c|c|c|c|}
\hline \multicolumn{2}{|c|}{} & Frequency & Valid Percent & Cumulative Percent \\
\hline \multirow{3}{*}{ Valid } & less than a year & 8 & 11.6 & 11.6 \\
\cline { 2 - 5 } & 1-3 years & 18 & 41.9 & 53.5 \\
\cline { 2 - 5 } & 4-9 years & 49 & 46.5 & 100.0 \\
\cline { 2 - 5 } & Total & 63 & 100.0 & \\
\hline
\end{tabular}

Table 8: Experience of the Respondents Source: Primary Data. (2017)

Table 8from the table it can be deduced that out of 75 of the total respondents. 8 work for less than a year, representing $11.6 \%$ of the total population. 18 have an experience of $1-3$ years, representing $41.9 \%$ and 29 had work experience of 4-9 years, representing $46.5 \%$ of the entire population. This implies that the county has experienced workers.

\subsection{Relationship between the Study Variable}

Important to the successful completion of this dissertation was to find out the relationship between Gender Violence, Human Wright and Peacebuilding in Jubek State.

\begin{tabular}{|c|c|c|c|c|}
\hline \multicolumn{2}{|c|}{ Gender Violence (1) } & 1 & 2 & 3 \\
\hline \multirow{2}{*}{} & & 1.000 & & \\
\cline { 2 - 5 } & &. & & ${ }^{* *}$ \\
\cline { 2 - 5 } & Human Wright (2) & $.787^{* *}$ & 1.000 & 1.000 \\
\cline { 2 - 5 } & & & $.765^{* *}$ &. \\
\cline { 2 - 5 } & Peace Building (3) & $.798^{* *}$ & & \\
\cline { 2 - 5 }
\end{tabular}

Table 9: Spearman`Zero Order Correlation Matrix Source: Primary Data. (2017)

Spearman correlation was used to determine relationship between the study variables as shown in the Table 9above.

\subsubsection{The relationship between Gender Violence and Peace Building}


The results in the Table 9indicated a significantly strong positive relationship between Gender Violence and Peace Building $(r=0.798$, P-value<0.01). This implies that Gender Violence has a negative relationship with Peace Building. Thus, the question of whether Gender violence has a negative relationship with peace building in the Jubek was answered as true. The implication of these findings is that without local government campaigns for gender violence, peace building will not be achieved in Jubek.

\subsubsection{The relationship between Norms and Gender Bases Violence}

The results in Table 9indicate a significantly strong negative relationship between Norms and Gender Bases Violence $(\boldsymbol{r}=0.787$, P-value $<0.01)$.The implication of these findings is that with the prevalence of social norms that will favor everyone, the gender base violence was attended and vice versa.

\subsection{Regression Model For Gender Violence, Human Wright And Peace Building}

Table 10 below shows the regression model for Gender Violence, Human Wright and Peace Building in Juba County Jubek State

\begin{tabular}{|c|c|c|c|c|c|c|}
\hline \multicolumn{8}{|c|}{$\begin{array}{c}\text { Coefficients } \\
\text { Peace Building }\end{array}$} & $\begin{array}{c}\text { Unstandardized } \\
\text { Coefficients }\end{array}$ & $\begin{array}{c}\text { Standardized } \\
\text { Coeffients }\end{array}$ & T & \\
\cline { 2 - 5 } & $\mathrm{B}$ & Std. Error & Beta & Std. Error & & .000 \\
\hline (Constant) & 2.718 & .131 & & & 20.706 & .003 \\
\hline Human Wright & .172 & .057 & .349 & .115 & 3.022 & .001 \\
\hline Gender Violence & .288 & .083 & .456 & .132 & 3.461 & \\
\hline$R=0.869, \mathrm{R}-$ Square $=0.755$, AdjustedR - square $=0.751, \mathrm{~F}=0.595$, Sig0.593 \\
\hline
\end{tabular}

The results in the Table 10 above indicate a linear relationship between Gender Violence Human Wright, and Peace building $(F=0.595, \mathrm{Sig}=0.593)$. Gender violence and Human Wright are the great drivers of peace building in any country.

Human Wright $($ Beta $=0.456$ explained more to Gender Violenceand peace building $($ Beta $=0.349)$.This implies that Gender violence and entirely influenced the peace building process in juba county.

\subsubsection{Factor Analysis Results of Gender Base Violence}

\begin{tabular}{|c|c|c|c|}
\hline Variable Attributes & 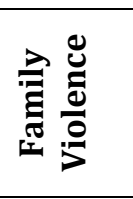 & 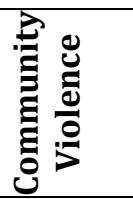 & 莺 \\
\hline There is high violence in the family & .987 & & \\
\hline Women are victim of family violence & 867 & & \\
\hline Family violence is cause by drugs especially men that drinks alcohol. & .895 & & \\
\hline $\begin{array}{l}\text { The county government has taken serous step toward combating family } \\
\text { violence by punishing those who are against women. }\end{array}$ & .875 & & \\
\hline Communities of juba county are more violence & & .891 & \\
\hline The community of Mundari involve in more violence with other communities. & & .981 & \\
\hline $\begin{array}{l}\text { This style is also used when the new approach is to be used in the very near } \\
\text { future. }\end{array}$ & & .892 & \\
\hline $\begin{array}{l}\text {. It may solve the conflict for the other party, but a conflict will begin in } \\
\text { manager. This style is not objective }\end{array}$ & & .913 & \\
\hline South Sudan has border disputes with north Sudan. & & & .871 \\
\hline $\begin{array}{l}\text { The two communities of Toposa of south Sudan and Turkana of Kenya are } \\
\text { always involves in fighting }\end{array}$ & & & .875 \\
\hline Top leadership mismanagement the resources of the county & & & .875 \\
\hline There are more corruption cases in this county & & & .891 \\
\hline Eigen value & 1.576 & 1.498 & .599 \\
\hline Variance \% & 38.973 & 31.343 & 19.354 \\
\hline Cumulative variance $\%$ & 38.973 & 60.313 & 80.789 \\
\hline
\end{tabular}

Table 11: Factor Loadings of Gender Base Violence Source: Primary Data, (2017) 
The results in the above table shows how the factor loading do confirm that Gender Violence in Juba county is measured by Family Violence, Community Violence, and State Violence, hypothesized in the conceptual framework (Figure 1.)

In the results of factor analysis of conflict resolution three factors were extracted and the first attribute (Family Violence) explained Gender Base Violence in the county better with $76.1 \%$, the second attribute (Community Violence) also explained Gender Base Violence in the County with 87.1\%, the third attribute (State Violence) also explained Gender Base Violence with $87.5 \%$

\subsubsection{Factor Analysis Results for Human Wright}

\begin{tabular}{|c|c|c|c|}
\hline Variable Attributes &  & 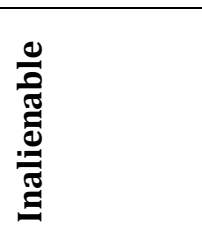 & 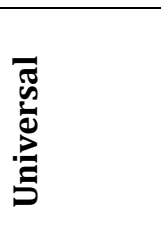 \\
\hline $\begin{array}{l}\text { HumanRights are inherent because they are not } \\
\text { granted by any person or authority }\end{array}$ & .953 & & \\
\hline Human Wright are universal to every one & .935 & & \\
\hline $\begin{array}{c}\text { Human rights do not have to be bought, earned } \\
\text { or inherited; they belong to people simply } \\
\text { because they are human }\end{array}$ & .928 & & \\
\hline Human rights are inherent to each individual & .865 & & \\
\hline $\begin{array}{l}\text { Human rights cannot be taken away; no one has } \\
\text { the right to deprive another person of them for } \\
\text { any reason. }\end{array}$ & & .863 & \\
\hline $\begin{array}{c}\text { People still have human rights even when the } \\
\text { laws of their countries do not recognize them, or } \\
\text { when they violate them }\end{array}$ & & .872 & \\
\hline $\begin{array}{l}\text { That which is inalienable cannot be bought, sold, } \\
\text { or transferred from one individual to another. }\end{array}$ & & .857 & \\
\hline $\begin{array}{l}\text { The personal rights to life and liberty guaranteed } \\
\text { by the Constitution. }\end{array}$ & & .775 & \\
\hline $\begin{array}{l}\text { Human Rights are universal in application and } \\
\text { they apply irrespective of one's origin, status, or } \\
\text { condition or place where one lives }\end{array}$ & & & .963 \\
\hline $\begin{array}{l}\text { Human rights are enforceable without national } \\
\text { border }\end{array}$ & & & .935 \\
\hline $\begin{array}{l}\text { Human rights are the same for all human beings } \\
\text { regardless of race, sex, religion, political or other } \\
\text { opinion, national or social origin. }\end{array}$ & & & .835 \\
\hline $\begin{array}{l}\text { We are all born free, and equal in dignity and } \\
\text { rights- human rights are universal. }\end{array}$ & & & .937 \\
\hline Eigen value & 1.605 & 1.589 & 1.503 \\
\hline Variance \% & 41.333 & 38.749 & 23.458 \\
\hline Cumulative variance $\%$ & 41.333 & 81.092 & 94.65 \\
\hline
\end{tabular}

\section{Table 12: Factor loading of Human Wright}

Source: Primary data. (2017)

The Table 12.shows the factor analysis results of Human Wright, three factors were extracted and the attribute (Inherent:) explained Human Wright better with 96.2\%, the second attribute (Fundamental) explained more of Human Wright with 91.5\% and Third attribute (Interdependent) explain Human Wright with 87.9\%.

The factor analysis of Human Wright explained that the county has serious cases of gender inequality by $96.2 \%$. 


\subsubsection{Factor Analysis Results Of Peace Building}

\begin{tabular}{|c|c|c|c|c|}
\hline Variable Attributes &  &  & 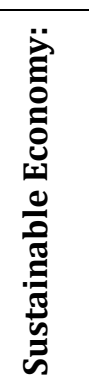 &  \\
\hline $\begin{array}{l}\text { A safe and secure environment is one in which the } \\
\text { population has the freedom to pursue daily activities } \\
\text { without fear of politically motivated, persistent, or } \\
\text { large-scale violence }\end{array}$ & .862 & & & \\
\hline $\begin{array}{l}\text { the protection of key individuals, communities, sites, } \\
\text { and infrastructure; and the freedom for people and } \\
\text { goods to move about the country and across borders } \\
\text { without fearof undue harm to life and limb. }\end{array}$ & .894 & & & \\
\hline $\begin{array}{l}\text { The most immediate concern is personal physical } \\
\text { safety from violence. }\end{array}$ & .952 & & & \\
\hline $\begin{array}{l}\text { State authority and security institutions, meanwhile, } \\
\text { are likely to be politicized, part of the problem, and } \\
\text { severely impaired or nonexistent, creating a security } \\
\text { vacuum that insurgents, terrorists, extremists, or } \\
\text { criminals will seek to fill. }\end{array}$ & .965 & & & \\
\hline $\begin{array}{l}\text { Ability of the people to have equal access to just laws } \\
\text { and a trusted system of justice that holds all persons } \\
\text { accountable, protects their human rights, and } \\
\text { ensures their safety and security. }\end{array}$ & & .972 & & \\
\hline $\begin{array}{l}\text { Rule of Law It is widely political consensus that the } \\
\text { rule of law is a necessary foundation for efforts to } \\
\text { achieve the goal of good governance. }\end{array}$ & & .876 & & \\
\hline This county observes the international human right & & .896 & & \\
\hline $\begin{array}{l}\text { Justice is valued as central in governance. Therefore, } \\
\text { it values justice as most important for establishing a } \\
\text { just society in which people from all walks of life, } \\
\text { from different faiths can live in peace and harmony } \\
\text { with no discrimination. }\end{array}$ & & & & .947 \\
\hline $\begin{array}{l}\text { The communities of this county live mutually with } \\
\text { one other }\end{array}$ & & & & .899 \\
\hline $\begin{array}{l}\text { Stable governance is the mechanism through which } \\
\text { the basic human needs of the population are largely } \\
\text { met, respect for minority rights is assured, conflicts } \\
\text { are managed peacefully through inclusive political } \\
\text { processes, and competition for power } \\
\text { occurs nonviolently. }\end{array}$ & & & .788 & .799 \\
\hline $\begin{array}{l}\text { There are rules and regulations which guide the } \\
\text { society }\end{array}$ & & & .799 & .896 \\
\hline $\begin{array}{l}\text { Stable governance refers to an end state where the } \\
\text { state provides essential services and serves as a } \\
\text { responsible steward of state resources. }\end{array}$ & & & .987 & \\
\hline $\begin{array}{l}\text { Economic stability refers to an absence of excessive } \\
\text { fluctuations in the macro-economy. An economy with } \\
\text { fairly constant output growth and low and stable } \\
\text { inflation would be considered economically stable } \\
\text { (Shumway, }\end{array}$ & & & .967 & .897 \\
\hline $\begin{array}{l}\text { Stable governance is the mechanism through which } \\
\text { the basic human needs of the population are largely } \\
\text { met, respect for minority rights is assured, conflicts } \\
\text { are managed peacefully through inclusive political } \\
\text { processes, and competition for power } \\
\text { occurs nonviolently. }\end{array}$ & & & .766 & \\
\hline
\end{tabular}




\begin{tabular}{|c|c|c|c|c|}
\hline Variable Attributes & 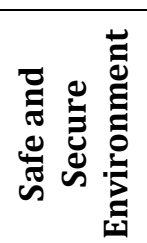 & 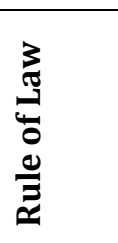 &  & 莺 \\
\hline $\begin{array}{l}\text { A financial system is stable when it dissipates } \\
\text { financial imbalances that arise endogenously or as a } \\
\text { result of significant adverse and unforeseeable } \\
\text { events. When stable, the system absorbs shocks } \\
\text { primarily via self-corrective mechanisms, preventing } \\
\text { the adverse events from disrupting the real economy } \\
\text { or spread over to other financial systems. }\end{array}$ & & & .876 & \\
\hline $\begin{array}{l}\text { financial stability is essential for maintaining } \\
\text { confidence in the economy. Possible consequence of } \\
\text { excessive instability includes: bank runs, } \\
\text { hyperinflation, or stock market crashes. }\end{array}$ & & & .755 & \\
\hline Eigen value & 1.161 & 1.005 & & .651 \\
\hline Variance $\%$ & 32.871 & 28.454 & & 18.431 \\
\hline Cumulative variance \% & 32.871 & 61.325 & & 79.756 \\
\hline
\end{tabular}

The results in the Table 13above shows how the factor loading do confirm Peace Buildingis measured by Safe and Secure Environment and Rule of Law ,and Sustainable Economy:

l, Stable Governance in Society as hypothesized in conceptual framework (figure1.1)

In the results of factor analysis of Peace Building, three factors were extracted the first attribute (Safe and Secure Environment) explained Peace Building better with 93.5\%, the second attribute ( Rule of Law) also explained more of peace building with $89.4 \%$, lastly (Stable Governance) explained peace building with $97.2 \%$. The factor analysis of peace building attribute explained that there is independence of county by $91.7 \%$ which enable it top leadership to delivery services to citizens of $89.9 \% . s$

\section{Discussion of Findings}

\subsection{Introduction}

This chapter presents interpretation of the study findings

\subsection{Bio Data}

\subsubsection{Gender of the Respondents}

The results indicated that $72 \%$ were males while the remaining $28 \%$ were females respectively. This implies that most of the respondents are male. The big number of male respondents indicated that most employees of the Juba County are males. It showed that the County employed more men than women.

\subsubsection{Age of the Respondents}

The results showed that $23.3 \%$ of the participants belonged to age group $18-25$ years, $48.8 \%$ belonged to age group $26-35$ years, $13.9 \%$ belonged to age group $36-46$ years and $4.7 \%$ belonged to age group $56-60$ years and $9.3 \%$ were above 60 years.

This implied that people who are engaged with the Juba County that ensure productivity and performance are between the age of 26-35 years, and indicator that the county employed people who are mature and energetic that can carry out duties and services effectively for the achievement of goals.

\subsubsection{Marital Status of the Respondents}

The results indicated that $48.8 \%$ of the participants were married, $11.6 \%$ were singles, $18.6 \%$ were divorce, $4.7 \%$ were separated, and $16.3 \%$ were widowed. This implied that most of respondents who were married have responsibilities and mindful about the continuation of their assignment and ensuring effective of conflict resolution in Juba County.

\subsubsection{Education Levels of the Respondents}

The results of the study indicated that $25.6 \%$ had stopped their learning in secondary school, $11.6 \%$ of the respondents were having Diploma, $46.5 \%$ were bachelor holders, and $16.3 \%$ were having Master degree. This implied that most of the staff in the county had the skills to plan and control activities of county and ensures conflict resolution. 


\subsubsection{Number of Years the Respondents Has Been in Service with Juba County}

The results of the study indicated that $11.6 \%$ had been in service with the county for $<1$ year, $41.9 \%$ had been in service with the county for 1-3 years, $46.5 \%$ had been in service with the county for $4-9$ years. This implied that most of the respondents had a high working experience of 4-9 years an indication that data obtained was from right people, an indication for lack of biasness in the data collection process.

\subsection{Relationship between the variables}

\subsubsection{The Relationship between Gender Violence and Peace Building}

The results in the Table 3indicated a significantly strong positive relationship between Gender Violence and Peace Building $(\boldsymbol{r}=0.798$, P-value $<0.01)$. This implies that Gender Violence has negative roles in Peace Building in the South Sudan. The implication of these findings is that without gender balance from local government and organization in place, Peace Building in the county will be negatively affected in south Sudan

\subsubsection{The Relationship between Human Wright and Peace Building}

The finding indicates a significantly strong positive relationship between Human Wright and Peace Building $(r=0.789$, P-value $<0.01)$.The implication of these findings is that with proper governance in the county the gender base can be stop and all citizens will enjoy services.

\subsubsection{Regression Model for Gender Violence Inequality, Human Wright and Peace Building}

The regression model for Gender violence, Human Wright and Peace Building in juba County in Jubek state, the results of study indicate a linear relationship between Gender Violence, Human Wright and Peace Building $(r=0.798$, Pvalue $<0.01)$ from which Human Wright $($ Beta $=0.456)$ explain more to Gender Violence follow by Peace Building $($ Beta $=0.349)$ that entirely influenced the Peace Building in juba county

- Acknowledge that a difficult situation exists. Honesty and clear communication play an important role in the resolution process. Acquaint yourself with what's happening and be open about the problem.

- Let individuals express their feelings. Some feelings of anger and/or hurt usually accompany conflict situations. Before any kind of problem-solving can take place, these emotions should be expressed and acknowledged.

- Define the problem. What is the stated problem? What is the negative impact on the work or relationships? Is differing personality styles part of the problem? Meet with employees separately at first and question them about the situation.

- Determine underlying need. The goal of conflict resolution is not to decide which person is right or wrong; the goal is to reach a solution that everyone can live with. Looking first for needs, rather than solutions, is a powerful tool for generating win/win options. To discover needs, you must try to find out why people want the solutions they initially proposed. Once you understand the advantages their solutions have for them, you have discovered their needs

\section{Conclusion and Recommendations}

\subsection{Introduction}

This chapter highlights the major conclusions and recommendations of the study. The findings are outlined in direct response to the objectives of the study. Recommendations have been provided to incorporate Gender Violence and Human Wright with the aim of promoting peace building in south Sudan.

\subsection{Conclusions}

The study examines those variables including Gender Violence and Human Wright with the aim of promoting peace building. This trend shows that there is a need to campaigns for the change about gender inequality by local government to stop gender base violence among the citizens.

\subsubsection{The Relationship between Gender Violence and Peace Building}

The study had shown that lack of proper governance policy has leads to increase on Gender Inequality in the Juba County as indicated by $(r=0.798$, $\mathrm{p}$-value $<0.01)$.The study recommends that,

- Create public awareness about GBV

- Provide life-skills training to the survivors of GBV

- Enact laws and effectively implement programs

- Ensure sufficient, trained health care providers and police officers to handle GBV cases

- Develop strategies to engage men in GBV prevention

\subsubsection{The Relationship between Human Wright and Peace Building}

The study indicates a negative relationship between Human Wright and Peace Building $(\boldsymbol{r}=\mathbf{0 . 7 8 9}$, P-value $<$

0.01). The implication of these findings is that with proper governance the peace building can be achieved in the country.

- Raise awareness. There are many facts and issues that the public at large is unaware of, especially the state of women in developing countries, including the realities of female child abuse and sexual violence. Talk about what 
you know. Increase public consciousness of the reasons for, extent of, and consequences of rape and sexual assault, sexual harassment, and pornography.

- Involvement in politics. There are many social and political reforms across the globe promoting women's rights that are in need of support. Find some and pick one to become involved in, and then petition, petition, petition until you see change...and you will!

- Be an activist. You can form your own activist committee! Work as a team to raise funds to spread awareness and build educational institutions across the world. You can be a part of it!

- The county should adapt decentralization as the governance system so that services are bringing close to the citizens.

\subsubsection{The Factor Structure of Gender Violence, Human Wright and Peace Building}

The study recommends that,

\subsubsection{Increase Women's Participation in Peacebuilding}

- Provide backstopping and 'surge support' to facilitate women's participation in all relevant peacebuilding processes, national steering committees, women's machinery and other relevant regional and international processes;

- Ensure gender expertise on all PBC assessment and field missions and visits and country specific meetings, both formal and informal;

- Convene civil society dialogues focused on gender and peacebuilding issues and help bridge the disconnect between indigenous women's organizations and the operational activities of international organizations.

6.2.3.2. Strengthen Institutional Capacity for Gender Equality and Peacebuilding

- Support institutional strengthening of women's peacebuilding organizations;

- Support catalytic activities at country level which are essential for implementing Peacebuilding Frameworks;

- Strengthen institutional capacity throughout the UN system in support of gender equality and peacebuilding aims.

\subsubsection{Respond to Gaps in Knowledge and Information on Gender and Peacebuilding}

- Support research and interdisciplinary collaboration on critical gaps and strategic priorities relevant to women and peacebuilding;

- Systematically collect information on lessons learned in UN peacebuilding missions and relevant post-conflict settings;

- Specify gender equality indicators as part of ongoing efforts to further develop monitoring and tracking mechanisms to follow up gender equality commitments made in the context of Peacebuilding Frameworks.

6.2.3.4. Increase Coherence of UN Actions in Support of Gender Equality and Peacebuilding

- Ensure that the priorities established in the peacebuilding frameworks and strategies reflect best practices for achieving gender equity and supporting women's participation in peacebuilding; engage appropriate partners (across the UN system, at national and regional levels and with civil society); and are appropriately resourced;

- Develop system wide policy coherence on women and peacebuilding.

\subsubsection{Ensure Adequate Resources to Mainstream Gender Equality into Peacebuilding}

- Establish a Trust Fund for Women and Peacebuilding with the aim of supporting strategic and catalytic activities to strengthen capacity, respond to critical gaps and strategic priorities within the field of gender and peacebuilding;

- Require that gender analysis be included in all priority plans and budgets, specifying intended beneficiaries, indicators and benchmarks for achieving gender equality aims;

- Encourage the establishment of allocation mechanisms that ensure an adequate proportion of funding is allocated for gender sensitive programming.

\subsection{Recommendations}

Basing on the study findings and the conclusions, the researcher derived the following recommendations.

Today, there is a clear consensus that good governance is indispensable for socio-economic development. It implies efficient and accountable institutions -- political, judicial, administrative, economic, and corporate - and entrenches rules that promote development, protection of human rights, respect of the rule of law, and ensure that people are free to participate in those issues that affect their lives. Obviously good governance is essential pre request for any country's development and to make the state and the political system workable and suitable for the people.

\subsubsection{Raise Awareness of GBV}

The study found a low level of community awareness of a number of factors that may contribute to women's vulnerability to VAW and hinder effective responses. A holistic awareness-raising campaign incorporating both mass media and people-to-people outreach (such as through community credit groups, women's groups and community clubs) should be launched. While mass media can be an effective way to disseminate new information, our study found that almost one third of female respondents were not exposed to media on a regular basis, and media exposure was correlated 
with age, class, education, economic status, and other variables, requiring a sophisticated approach to tailoring both message and message delivery.

Other differences identified by the study, related to risk factors, should also be considered (see 'enhance the evidence base,' below). Finally, as the study found among women interviewed that a majority of those who had experienced violence either did not report it, or reported it only to friends or family, these protective networks should be utilized and enhanced.

- Develop a variety of targeted outreach messages and mechanisms that effectively reach men and women within their communities, considering mass media accessibility, and taking into account high levels of illiteracy.

- Key messages would include: 1) the rights of all Nepalese under the specific laws related to VAW and GBV; 2) the important role family members and friends can play in preventing VAW and GBV, as well as helping victims seek assistance and justice; 3) the kinds of assistance available, both generally and locally (e.g., the GBV elimination fund, women's police cells, and the role of Women Human Rights Defenders), since a quarter of woman respondents said they didn't believe reporting would make a difference.

- Develop targeted awareness programs for community leaders (e.g., traditional power holders such as priests, retired politicians/ village leaders) and for wider communities, emphasizing women's economic and political roles as agents of development.

- This message should promote the understanding that women are not responsible for family ijaat, and foster a positive image of women as economic actors holding equal rights to men - constitutionally, legally, socially and culturally.

\subsubsection{Develop Innovative Mechanisms for Increasing Policy and Program Accountability}

A key finding from the IDIs and FGDs across a range of stakeholders was the perception that state-mandated mechanisms for addressing violence were not fully implemented, due in part perhaps to the community's lack of knowledge of their rights and entitlements, and in part to a lack of capacity among 'street level' bureaucrats to address the issue (Walker and Gilson, 2004). The capacity to implement policies and programs, and accountability for that implementation, must be increased, and we suggest that innovative new mechanisms for increasing accountability be considered.

These might include community-led mechanisms, such as those used, for example, to report on the presence or absence of 'front-line workers' (health care workers, teachers, etc) at their posts (see, for example, the work of Ushahidi.com). This would also increase the community's sense of ownership of solutions to VAW, which the study indicated community members felt was appropriate.

- $\quad$ Promote community-led use of mobile phone technologies and community radios to assess and record program delivery and effectiveness.

\subsubsection{Address Potential Drivers of GBV}

In focus group discussions, in interviews with key decision makers, and among both men and women, the study found a great deal of consensus regarding why violence happens. These views were then echoed in subsequent interviews with key decision makers at the national and district levels. These common views of social and structural dynamics, along with data gleaned from the quantitative study, can be used to identify potential entry points to reduce risks of VAW.

- Increase community-level efforts to advance women's empowerment in order to address some of the potential drivers of VAW, including women's isolation from the rest of the community and limited access to education and employment opportunities.

- Identify potential entry points that reduce VAW risks, and launch pilot interventions, such as creating more opportunities for women to become linked, in ways that are locally appropriate, to other social circles in the communities in which they live.

\subsection{Areas for Further Research}

- Support actions that men and women are taking to prevent violence.

- Support the establishment of early warning systems that gather information from men and women from all classes of society.

- Make sure women and men are involved in discussions about your agency's reconstruction priorities.

- Support legislative reforms that promote equal rights of women and men.

- Support programmes targeting the reduction of domestic violence (domestic violence tends to increase in the immediate post-conflict period).

- Make sure your staff members abide by the code of conduct of your development agency to prevent the sexual abuse of women and girls, men and boys.

- Send gender-balanced teams to the field to implement your agency's programmes.

\section{Dedication}

I would like to dedicate the success of this study to my wife Elizabeth Atong Abuoi, My Daughter Manyinadhieu Yar Alier, Mary Anai Agaau,Monica Adhieu Alier, Adhieu Alier Riak, Riak Alier Riak, Jooh Alier Known as Ngarachiek, Nancy Ayuen Alier, Arik Alier Riak, My Wife Recel Amuor Manyang, Jacob Matiop Agau, Peter Agot Alier and My Father In-law James Abuoi Amach who always encouraging me to study, My Mother in-law LateAthieng Nhail, my Brother in-law Michael 
Amach Abuoi, Agot Agau Riak, brothers, sisters and friends for their continued support in the process of carrying out the study and subsequently giving encouragement during the development of this report. Their ideas and moral support gave me strength and energy to accomplish this study.

\section{Acknowledgement}

It is essential to recognise the contribution of Ustaz James Ajuong Arou, Gen James Ajongo Mawut, Honorable Stephen Ajongo Akol, Maj Hanibol Majok, Wilson Mading Deng, Lt.Gen Malual Ayom, Col Dor Dut Dor.Brig.Gen Gen Riak Machuor Kulang, Alier Joo Riak, Ngong David Kucha, James Ayuen Alier, Mawut Ngong Alier, Johnson Mabior Makuei, Panchol Alier Makuei, Jok Makuei Ajak, Mawut Makuei Ajak, Jok Makhor Jokand different individuals and institutions without which this report wouldn't have been possible. I would like to express my sincere gratitude and appreciation to the god Lord for enabling and guiding me through my academic life. I am grateful to Star international University College for admitting me to their LAW program. Special thanks to my supervisor Anyang Jacob Makol who guided me throughout the entire work.

Special thanks also go to the employees of the leaders and Citizens of Central Equatoria State for sparing their time for interviews and to fill in questionnaires, without them, this research would not have been done. I once again thank all, including the categories not mentioned above, who encouraged and contributed to the completion of this work

\section{References}

i. World report on violence and health. Geneva, World Health Organization, 2002.

ii. Lansford JE, Dodge KA. Cultural norms for adult corporal punishment of children and societal rates of endorsement and use of violence. Parenting: Science and Practice, 2008, 8:257-270.

iii. Abrahams N, Jewkes R. Effects of South African men's having witnessed abuse of their mothers during childhood on their levels of violence in adulthood. American Journal of Public Health, 2005,

iv. Brookmeyer KA, Henrich CC, Schwab-Stone M. Adolescents who witness community violence: can parent support and prosocial cognitions protect them from committing violence? Child Development, 2005, 76:917929.

v. Johnson, JG et al. Television viewing and aggressive behavior during adolescence and adulthood. Science,2002, 295:2468-2471.

vi. Durlauf SN, Blume LE. New Palgrave Dictionary of Economics, Second Edition. London, Macmillan, 2008.

vii. Lewis D. Convention: a philosophical study. Cambridge MA: Harvard University Press, 1969.

viii. Mitra A, Singh P. Human capital attainment and gender empowerment: the Kerala paradox. Social Science Quarterly, 2007, 88:1227-1242.

ix. Ilika AL. Women's perception of partner violence in a rural Igbo community. African Journal of Reproductive Health, 2005, 9:77-88.

x. Jewkes R, Penn-Kekana L, Rose-Junius H. “If they rape me, I can't blame them': reflections on gender in the social context of child rape in South Africa and Namibia. Social Science and Medicine, 2005,

xi. Hussain R, Khan A. Women's perceptions and experiences of sexual violence in marital relationships and its effect on reproductive health. Health Care for Women International, 2008, 29:468-483.

xii. Sable MR et al. Barriers to reporting sexual assault for women and men: perspectives of college students. Journal of American College Health, 2006,

xiii. WHO global status report on alcohol 2004. Geneva, World Health Organization, 2004. 